\title{
KETERLAMBATAN PENYELESAIAN SKRIPSI MAHASISWA ANGKATAN 2012 \\ (STUDI KASUS DI JURUSAN EKONOMI PEMBANGUNAN FAKULTAS EKONOMI UNIVERSITAS NEGERI MALANG)
}

\author{
Evi Nur Aslinawati ${ }^{1}$, Sri Umi Mintarti $\mathbf{W}^{2}$ \\ 1. Economic Education Program, Faculty of Economics, State University Malang \\ 2. Economic Education Program, Faculty of Economics, State University Malang \\ aslinawati18@gmail.com, sriumi.mintarti@um.ac.id
}

\begin{abstract}
This study departs from the problem of the number of students who have delayed graduation because they cannot complete the thesis on time. For that, it is necessary to do research to determine the cause of thesis by the students. The type of research conducted is qualitative descriptive, with the location of research in Economic Development Department Faculty of Economics, State University of Malang. Technical data is done through. Data analysis is done in data processing, presentation, and data verification. The result of research indicates the existence of internal factor causing delays of completion of thesis of health factor, weakness of motivation, interest, level of intelligence (IQ, SQ, AQ, and EQ), difficulty in determining research topic, accuracy in collecting data and analyzing research data, Scientific papers, work, active organization, and low ability of students in time management. While external factors include the motivation of the family, interest in reference, the relationship between lecturers and students, and the environment of peers.
\end{abstract}

Keywords: Thesis, Thesis Settlement Delay, Internal Factor and External Factor

History of Article:

Received: (08 Januari 2017), $\quad$ Accepted: (03 Februari 2017), Publised: (15 Mare 2017)

\section{Citation:}

Aslinawati, Evi Nur \& Sri Umi Mintarti (2017) Keterlambatan Penyelesaian Skripsi Mahasiswa Angkatan 2012 (Studi Kasus Di Jurusan Ekonomi Pembangunan Fakultas Ekonomi Universitas Negeri Malang). [Delayed Completion of Student Thesis Force 2012 (Case Study In Economic Development Department Faculty of Economics, State University of Malang)]. Jurnal Pendidikan Ekonomi, 10(1), 23-33.

(C) UniversitasNegeri Malang 


\section{PENDAHULUAN}

Banyaknya mahasiswa yang tidak dapat lulus tepat waktu akan memberikan berbagai dampak negatif bagi pihak universitas maupun bagi pihak mahasiswa itu sendiri. Berdasarkan catatan di Bidang Akademik Fakultas Ekonomi (10/08/2016), masih terdapat 201 dari 350 mahasiswa angkatan 2012 (memasuki semester ke 9) yang belum lulus di Jurusan Ekonomi Pembangunan Universitas Negeri Malang (EKP FE-UM). Hal ini dikarenakan para mahasiswa mengalami kendala dalam menyelesaikan skripsi mereka.

Skripsi merupakan salah satu mata kuliah wajib yang harus ditempuh seorang mahasiswa sebagai salah syarat kelulusan untuk meraih gelar akademiknya. Mariana (2013) mendeskripsikan skripsi sebagai "tugas akhir dimana mahasiswa melakukan sebuah penelitian pada kasus-kasus atau fenomena yang muncul dan kemudian diteliti dengan menggunakan teori-teori relevan yang sudah dipelajari selama masa perkuliahan dan akhirnya akan dianalisis untuk mendapatkan hasil dari penelitian tersebut."

Sedangkan Dalam Pedoman Pendidikan UM pasal 42 (1) (2012: 51), skripsi didefinisikan sebagai berikut: "Merupakan karya ilmiah yang bersifat terapan ilmu, teknologi, dan seni yang ditulis oleh mahasiswa Progam Sarjana pada akhir masa studinya berdasarkan hasil penelitian, kajian teks (discourse analysis), kajian kepustakaan (literature research), penelitian pengembangan, atau pengembangan suatu karya yang dilakukan dengan mengikuti kaidah ilmiah."

Menurut Maanesh (2009: p.159) skripsi harus mengangkat sebuah topik yang bersangkutan dengan jurusan yang di ambil. Sehingga dapat disimpulkan bahwa agar lulus dalam mata kuliah skripsi, mahasiswa harus melakukan sebuah penelitian ilmiah yang dipertanggung jawabkan kepada dosen pembimbing dan penguji sesuai dengan disiplin ilmunya serta disusun untuk memenuhi persyaratan memperoleh gelar sesuai jenjang pendidikannya.

Hasil wawancara awal yang dilakukan peneliti terkait keterlamba-tan mahasiswa dalam menyusun skripsi ini, dikarenakan mahasiswa mengalami berbagai kendala baik dari faktor internal maupun faktor eksternal. Faktor internal yang pertama adalah faktor kesehatan. Menurut Slameto (2013: p.54) sehat berarti dalam keadaan baik segenap badan beserta bagian-bagiannya/ bebas dari penyakit. Kesehatan seseorang berpengaruh terhadap proses belajarnya. Khasanah (2015), menyatakan bahwa kondisi kesehatan seorang peserta didik yang kurang sehat dapat menurunkan tingkat konsentrasi peserta didik dan memungkinkan peserta didik akan sering meninggalkan aktivitas akademisnya untuk pemulihan atau pengobatannya. Pernyataan ini juga sesuai dengan hasil penelitian yang dilakukan oleh Kusnendar, dkk (2012) yang menyatakan bahwa mahasiswa yang mengalami kelelahan baik secara rohani maupun jasmani, dan meskipun penyakitnya tidak parah, namun hal ini dapat mempengaruhi penyelesaian skripsi mahasiswa.

Pada aspek kecerdasan peserta didik, dapat dibedakan menjadi IQ (Intelligence Quotient), EQ (Emotion Quottient), AQ (Adversity Quotient), dan SQ (Spiritual Quotient). Dimana, menurut Goleman (dalam Efendi, 2005) menegaskan bahwa setinggi-tingginya IQ menyumbang $20 \%$ bagi factor-faktor yang menentukan sukses dalam hidup. Sedangkan yang $80 \%$ diisi oleh factorfaktor lain. Goleman (dalam Baharuddin, dkk, 2010: p.155) juga melaporkan hasil penelitiannya pada tahun 1995 bahwa tingkat intelegensi yang tinggi tidak 
menjamin gengsi, kesejahteraan, kebahagiaan, dan kesuksesan hidup. Ada kecerdasan lain yang tidak kalah pentingnya, yaitu kecerdasan emosio-nal. Sehingga, dalam menghadapi dan menyelesaikan kesulitan-kesulitan dalam mmenyusun skripsi diperlukan ke-empat kecerdasan tersebut.

Faktor internal selanjutnya adalah motivasi lulus tepat waktu. Uno dalam Rusmiasih (2013) menyebutkan bahwa motivasi adalah "kekuatan baik dari dalam maupun dari luar yang mendorong seseorang untuk mencapai tujuan tertentu yang telah ditetapkan sebelumnya". Pada kasus mahasiswa tingkat akhir, motivasi lulus tepat waktu ini menjadi kunci dari terselesaikannya skripsi tepat waktu. Mereka yang memiliki motivasi ini, akan melakukan berbagai hal, dan memikirkan banyak cara untuk menghadapi setiap hambatan atau permasalahan yang ada. Semua ini dilakukan agar mereka bisa lulus tepat waktu. Pernyataan ini didukung oleh hasil penelitian yang dilakukan oleh Supiana, dkk (2013), yang menyatakan bahwa motivasi merupakan salah satu faktor yang turut menentukan keefektifan dan keberhasilan pembelajaran dan sangat besar pengaruhnya pada proses pembelajaran karena para peserta didik akan berusaha dengan sungguh-sungguh apabila mereka memiliki motivasi yang tinggi.

Salah satu faktor yang dapat mempengaruhi motivasi adalah minat mahasiswa dalam mengerjakan skripsi. Penelitian yang dilakukan oleh Putri dan Isnani (2015) menje-laskan bahwa yang besar terhadap sesuatu merupakan modal yang besar untuk mencapai atau memperoleh tujuan yang diminati, karena peserta didik dengan minat belajar yang tinggi akan senantiasa memberikan perhatian penuh dalam usahanya mencapai tujuan pembelajaran. Minat ini dapat dipicu dari ketertarikan mereka terhadap topik penelitiannya.

Ketika berbicara tentang kesulitan-kesulitan dalam pengerjaan skripsi, mahasiswa juga mengalami kesulitan seperti menentukan topik atau permasalahan penelitian, mengumpulkan data serta mengolah data. Hal ini sesuai dengan hasil penelitian Siswanto dan Sampuno (2012) terkait pengajuan judul yang menjadi salah satu faktor utama yang menghambat penyelesaian tugas akhir skripsi, dan diperkuat dengan hasil penelitian dari Wangid dan Sugianto (2013) yang menyatakan bahwa faktor utama yang mempengaruhi lambatnya mahasiswa dalam dalam menyelesaikan skripsi ini salah satunya adalah kesulitan menemukan permasalahan penelitian.

Sedangkan hasil penelitian dari Barnes (2014) juga menyatakan bahwa salah satu faktor yang menjadi alasan telatnya penyelesaian skripsi yaitu sulitnya memproses data yang terkait. Namun, bagi mahasiswa yang sudah berpengalaman dalam menulis karya tulis ilmiah, kesulitan-kesulitan ini akan mudah terselesaikan. Pernyataan ini sesuai dengan teori yang dikemukakan oleh Dalman (2014: p.32), yaitu pengalaman menulis karya tulis ilmiah dapat mengatasi kesulitan-kesulitan penelitian. Hartato (2016) juga menyebutkan bahwa dan salah satu penyebab utama skripsi dapat terselesaikan tepat waktu adalah kemampuan mahasiswa tersebut dalam menulis karya tulis ilmiah.

Kuliah sambil bekerja juga akan menghambat proses penyelesai-an skripsi, Pekerjaan/tugas di dalam bekerja yang banyak akan mengura-ngi fokus belajar dari para mahasiswa. Mahasiswa yang bekerja akan cenderung mendahulukan kepenti-ngan pekerjaannya daripada kegiatan perkuliahan. Kelelahan akibat belajar juga akan berdampak pada kemalasan mahasiswa dalam mengerjakan skripsi. Hal ini juga sesuai dengan penelitian yang dilakukan oleh Sudharta (2012), 
yang menyebutkan bahwa aktivitas bekerja memiliki pengaruh negatif terhadap prestasi belajar. Penelitian yang dilakukan oleh Pujiyanto (2005), juga menyatakan bahwa mahasiswa yang lebih mengutamakan pekerjaannya, akan mengalami penurunan IP di tiap semesternya.

Selain bekerja, aktivitas lain diluar perkuliahan seperti organisasi dapat mengganggu penyelesaian skripsi mahasiswa. Hal ini seperti yang di ungkapkan oleh Hamalik (2003: p.73) mengungkapkan "bahwa terlalu banyak berorganisasi adalah kurang baik dalam arti menyebabkan kelalian dalam belajar." Pernyataan dari Hamalik (2003: p.73) ini di dukung dengan hasil penelitian dari yang dilakukan oleh Marantika (2007) yang menyatakan bahwa keaktifan organisasi mahasiswa mempunyai pengaruh yang negatif terhadap prestasi belajar mahasiswa. Dikata-kan negatif karena keaktifan organisasi mahasiswa saat ini rendah, namun rendahnya keaktifan di organisasi ini diikuti dengan meningkatkan prestasi belajar.

Mahasiswa yang menyusun skripsi dituntut untuk dapat menyesuaikan diri dengan proses belajar individual, sehingga tuntutan akan belajar mandiri sangat besar. Widodo (2010) menyatakan bahwa keterampilan individual untuk mengatasi berbagai kendala dalam penyusunan skripsi, atau yang disebut dengan manjemen waktu inilah yang menentukan tingkat keberhasilan mahasiswa dalam menyelesaikan skripsi. Sehingga, kesulitan yang dialami mahasiswa satu dan yang lainnya pun berbeda. Mujahidah (2014) juga mendukung hasil penelitian dari Widodo (2010), dan menyatakan bahwa adanya hubungan negatif yang sangat signifikan antara manajemen waktu dengan tingkat kemalasan atau penundaan pengerjaan skripsi oleh mahasiswa. Menurut Timpe dalam Mujahidah (2014) ada enam aspek yang tidak boleh ditinggalkan jika hendak meningkat-kan pengelolaan waktu, yaitu : (1) kebiasaan menghabiskan waktu secara sia-sia, (2) penetapan sasaran, (3) penetapan prioritas, (4) komunika-si, (5) penundaan, (6) sikap asertif.

Sedangkan faktor eksternal yang menyebabkan keterlambatan penyelesaian skripsi yang pertama adalah kurangnya dukungan dari keluarga. Mushtaq dan Khan (2012), mengemukakan bahwa keluarga merupakan salah satu faktor yang mempenga-ruhi prestasi akademik mahasiswa. Penelitian yang dilakukan Hamidi, dkk (2013) juga menyatakan bahwa apabila mahasiswa dalam penyelesaian skripsinya dibantu dan dimotivasi oleh keluarga maka penyelesaian skripsi akan lebih baik.

Selain dukungan dari keluarga, faktor teman sebaya juga sangat berpengaruh dalam proses pengerjaan skripsi. Menurut Santrock (2012:109) teman sebaya adalah anak-anak dengan usia atau tingkat kedewasaan yang kurang lebih sama. Penelitian yang dilakukan oleh Korir dan Kipkemboi (2014), berhasil membuktikan bahwa lingkungan sekolah dan pengaruh teman sebaya membuat kontribusi yang signifikan terhadap prestasi akademik.

Tidak hanya hubungan mahasiswa dengan keluarga maupun teman sebaya. Relasi yang dibangun mahasiswa dengan dosen dosen pembimbing juga mempengaruhi proses pengerjaan skripsi. Relasi yang dimaksud disini adalah komunikasi dan intensitas bimbingan. Gunawati, dkk (2006) yang menjelaskan bahwa kegagalan dalam menjalin komunasi yang positif dengan dosen dapat menyebabkan terjadinya perselisihan pendapat, atau miss communication yang terjadi akibat adanya kesalahan dalam menginterpretasi arti pesan. Sedangkan 
menurut Wangid dan Sugiyanto (2014), "kehadiran dosen pembimbing menjadi sosok yang sangat penting dalam proses mengerjakan skripsi. Seorang dosen pembimbing skripsi memiliki tugas dan peran yang sangat menentukan dalam penyelesaian suatu skripsi”.

Faktor eksternal yang terakhir adalah sulitnya mencari referensi. Hartato (2016) menyebutkan bahwa adanya sumber belajar berupa referensi bagi mahasiswa merupakan suatu hal yang penting dalam bagi mahasiswa karena sumber belajar ini akan menjadi rujukan, acuan, dan pedoman dalam penyelesaian tugas akhir skripsinya.

Temuan peneliti ini mengarah kepada hasil penelitian yang dilakukan oleh Mushtaq dan Khan (2012), dengan hasil penelitian yang menyebutkan bahwa kualitas mahasiswa yang meliputi kemampuan komunikasi, fasilitas atau sarana prasarana, intensitas bimbingan dan hubungan keluarga memiliki penga-ruh terhadap prestasi mahasiswa. Hasil penelitian yang dilakukan oleh Hartato (2011) juga menunjukkan bahwa penyelesaian tugas akhir skripsi dipengaruhi oleh faktor-faktor sebagai berikut: motivasi lulus tepat waktu, kemampuan menulis karya tulis ilmiah, ketersediaan sumber belajar, kualitas bimbingan skripsi, dan pengaruh teman sebaya.

Faktor-faktor penghambat yang diungkapkan di atas bila tidak segera ditanggulangi, maka dikhawa-tirkan akan mengganggu sistem pendidikan di Jurusan EKP FE UM akibat menumpuknya mahasiswa. Selain itu, dikhawatirkan mahasiswa tersebut akan terkena Drop Out (DO). Oleh sebab itu peneliti tertarik untuk mengkaji lebih dalam mengenai faktor-faktor apa sajakah yang menghambat penyelesaian skripsi mahasiswa EKP FE UM. Sehingga judul dari penelitian ini adalah "Keterlambatan Penyelesaian Skripsi Mahasiswa (Studi Kasus di Jurusan Ekonomi Pembangungan Fakultas Ekonomi Universitas Negeri Malang Angkatan 2012)".

\section{METODE PENELITIAN}

Jenis penelitian yang digunakan adalah penelitian deskriptif kualitatif. Penelitian ini dilakukan di Jurusan Ekonomi Pembangunan Fakultas Ekonomi Universitas Negeri Malang untuk mahasiswa angkatan 2012, yang belum berhasil menyelesaikan studinya tepat waktu. Teknik pengumpulan data yang digunakan adalah metode wawancara mendalam dan dokumentasi. Dalam penelitian ini, analisis data dilakukan melalui tahap pengolahan data, penyajian data dan verifikasi data. Untuk mengecek keabsahan data, teknik utama yang peneliti gunakan adalah triangulasi teknik.

Data yang didapat peneliti berasal dari wawancara mendalam dengan 12 responden kunci yang dipilih berdasarkan teknik snawball sampling, yaitu mereka yang mengalami keterlambatan dalam penyelesaian skripsi; serta 4 informan yaitu 3 informan dari mahasiswa yang berhasil menyelesaikan skripsinya tepat waktu, dan 1 dosen.

\section{HASIL DAN PEMBAHASAN}

Keterlambatan penyelesaian skripsi oleh mahasiswa Jurusan EKP FE UM, disebabkan adanya faktor internal dan eksternal dari mahasiswa. 


\section{Faktor Internal}

Dalam faktor internal ini terdapat beberapa faktor yang menjadi penyebab keterlambatan penyelesaian skripsi mahasiswa, diantaranya faktor kesehatan. Kesehatan jasmani memiliki peran yang penting bagi para mahasiswa tingkat akhir dalam penyelesaian skripsi. Ketika mahasiswa sedang sakit atau merasa kecapekan, mahasiswa menjadi tidak bisa berkonsentrasi dan fokus dalam mengerjakan skripsi. Hal ini sesuai dengan hasil penelitian yang dilakukan oleh Khasanah (2015) dan juga Kusnendar, dkk (2012) tentang pengaruh kesehatan terhadap aktivitas akademik. Selain itu, jika mahasiswa tidak bisa berkonsentrasi sewaktu bimbingan, dapat membuat mahasis-wa tersebut sering lalai dengan tugas -tugas atau masukan yang telah diberikan dosen pembimbingnya, sehingga hal ini akan membuat inefektivitas dalam bimbingan yang telah dilakukan. Gangguan kesehatan juga membuat para mahasiswa beristirahat total dan pengerjaan skripsipun akan tertunda.

Selain faktor kesehatan, adapula faktor lemahnya motivasi yang merupakan faktor penghambat bagi seorang mahasiswa dalam menyelesaikan skripsi. Lemahnya motivasi mahasiswa dalam mengerja-kan skripsi, dipicu oleh beberapa faktor. Diantaranya, faktor lemahnya keinginan mahasiswa untuk segera lulus tepat waktu, rasa nyaman ada di Kota Malang, serta mainset bahwa mereka tidak akan lulus tepat waktu. Hal ini membuat para mahasiswa bermalas-malasan, menunda menger-jakan skripsinya, deadline dari jurusan tidak dapat dikejar dan akhir-nya mereka lulus melebihi jangka waktu normal menempuh pendidikan S1. Temuan penulis ini sejalan dengan hasil penelitian dari Supiana, dkk (2013). Motivasi ini merupakan cerminan dari kecerdasan emosi.

Selain tercermin dari motivasi, kecerdasan emosi, juga digambarkan melalui minat mahasiswa tersebut terhadap skripsi yang dikerjakan. Berbekal dengan minat para mahasis-wa terhadap topik yang diambilnya, mendorong mahasiswa lebih berse-mangat untuk cepat menyelesaikan skripsinya. Selain itu, meskipun mengalami berbagai kendala namun ketika para mahasiswa berminat terhadap penulisan skripsi mereka, maka kendala atau hambatan tersebut akan dapat segera terselesaikan. Hasil penelitian ini mendukung penelitian yang dilakukan oleh Putri dan Isnani (2015), yaitu motivasi yang besar terhadap sesuatu merupakan modal yang besar untuk mencapai tujuan yang diminati.

Mencari topik penelitian yang sesuai dengan minat mahasiswa dan standart penelitian yang telah di tetapkan dosen merupakan hal yang tidak mudah dilakukan. Siswanto dan Sampuno (2012) juga menyebutkan bahwa pengajuan judul menjadi salah satu faktor utama yang menghambat penyelesaian tugas akhir skripsi. Salah satu kendala dalam menentukan topik penelitian adalah ketidak pekaan atau kurangnya sensitivitas dari mahasiswa dalam mengidentifi-kasikan masalah penelitian yang pantas dijadikan penelitian. Semakin lama waktu yang mahasiswa butuh-kan dalam mencari topik penelitian, maka akan semakin lama pula waktu yang dibutuhkan para mahasiswa dalam menyelesaikan skripsi.

Tidak hanya pada penentuan topik penelitian, mahasiswa juga membutuhkan waktu yang lama untuk mengumpulkan data dan menganali-sisnya. Kesulitan dalam mengumpul-kan dan analisis data ini tergantung dengan metode penelitian, jenis data dan teknik analisis yang dipakai dalam penelitian masingmasing mahasiswa. Namun, tidak semua mahasiswa memiliki kemampuan atau 
dapat menguasai teknik pengambilan data maupun teknik analisis data tersebut. Keberhasilan pada tahap ini, selain diperlukan kecerdasan intelektual, juga dipengaruhi oleh kecerdasan emosial. Dalam penelitian yang dilakukan Barnes (2014) juga didapatkan bahwa sulitnya mempro-ses data menjadi penyebab telatnya penyelesaian skripsi.

Pada dasarnya kesulitan dalam pengerjaan skripsi seperti penentuan topik, pengumpulan dan analisis data tersebut disebabkan oleh kurangnya pengalaman dan lemahnya keterampi-lan mahasiswa dalam menulis karya tulis ilmiah. Ketika mahasiswa sudah terampil menulis karya tulis ilmiah, maka berbagai kendala akan dengan mudah dipecahkan, dan skripsi dapat terselesaikan tepat waktu. Pernyataan ini sesuai dengan teori yang dikemukakan oleh Dalman (2014:32), yaitu pengalaman menulis karya tulis ilmiah.

Faktor internal selanjutnya yang menghampat proses pengerjaan skripsi adalah aktivitas mahasiswa di luar akademik, seperti bekerja dan organisasi. Dengan bekerja dan berorganisasi, mahasiswa akan lebih terfokus dengan pekerjaan dan organisasinya, sehingga akan mengurangi waktu efektif yang dapat digunakan para mahasiswa untuk mengerjakan skripsi. Selain itu, efek kelelahan yang ditimbulkan dari padatnya aktivitas dapat mengurangi motivasi dan minat mahasiswa dalam mengerjakan skripsi. Akibatnya, proses pengerjaan skripsi pun akan terus tertunda. Hasil penelitian ini juga diperkuat dengan hasil penelitian yang dilakukan Pujiyanto (2005) dan juga Sudharta (2012) tentang dampak negatif dari bekerja, serta Hamalik dan Marantika tentang dampak negatif dari organisasi terhadap prestasi akademik.

Faktor terakhir yang mejadi alasan keterlambatannya mahasiswa dalam menyelesaikan skripsinya adalah manajemen waktu. Dalam penelitian ini, manajemen waktu dilihat dari 6 indikator (Timpe dalam Mujahidah, 2004), yaitu: (1) kebiasaan menghabiskan waktu secara sia-sia, (2) penetapan sasaran, (3) penetapan prioritas, (4) komunikasi, (5) penundaan, (6) sikap asertif. Berdasarkan hasil yang peneliti dapatkan, para mahasiswa yang belum dapat menyelesaikan skripsinya, tidak memiliki manajemen waktu yang struktur dalam mengerjakan skripsinya. Padahal, tanpa adanya manaje-men waktu yang terstruktur maka para mahasiswa tidak akan dapat mencapai tujuan akhirnya. Manajemen waktu ini akan membantu mahasiswa dalam memberikan gambaran yang jelas terkait halhal apa saja yang memungkinan dapat menjadi penghambat dalam kelanca-ran proses pengerjaan skripsinya. Sehingga, melalui manajemen waktu yang baik, mahasiswa dapat mengan-tisipasi segala kemungkinan buruk yang akan menghambat penyelesaian skripsinya, seperti memulai pengerjaan skripsi lebih awal. Bagaimana pentingnya manajemen waktu bagi mahasiswa juga dijelaskan oleh Widodo (2010).

\section{Faktor Eksternal}

Faktor eksternal merupakan faktor yang berasal dari luar diri individu, seperti faktor keluarga. Keeratan hubungan atau komunikasi antara mahasiswa dan keluarganya yang dicerminkan melalui perhatian dan pengertian yang di berikan keluarga menjadi pengingat, pem-bangkit semangat para mahasiswa untuk segera menyelesaiakan skripsi, dan membantu mahasiswa dalam memecahkan permasalahan yang sedang mahasiswa hadapi ketika mengerjakan skripsi. Penelitian dari Mushtaq dan Khan (2012) serta Hamidi, dkk (2013) juga 
menyebut-kan bahwa motivasi dari keluarga dapat membantu mahasiswa dalam proses penyelesaian skripsi.

Sama halnya dengan motivasi yang ditimbulkan oleh keluarga, terdapat pula pengaruh dari teman sebaya terhadap proses penyelesaian skripsi. Lingkar teman yang membe-rikan pengaruh yang positif akan memunculkan hubungan saling mem-beri motivasi, saling memberikan informasi dan saling membantu ketika mengalami kesulitan pengerjaan skripsi. namun, lingkar teman yang memberikan pengaruh negatif, akan membuat mahasiswa semakin malas dan enggan dalam mengerjakan skripsinya. Hal ini sesuai dengan penelitian yang dilakukan oleh Korir dan Kipkemboi (2014) tentang faktor yang mempengaruhi prestasi akademik mahasiswa.

Tidak hanya keluarga dan teman sebaya, relasi antara mahasiswa dengan dosen pembim-bing sangat menentukan kelancaran dari proses pengerjaan skripsi. Relasi yang dimaksud berupa kualitas komunikasi dan intensitas bimbingan. Kualitas komunikasi dapat dipenga-ruhi oleh lemahnya mental mahasiswa untuk menemui dosen pembimbing dan kurang mengertinya mahasiswa terhadap bahasa yang digunakan oleh dosen, seperti hasil penelitian dari Gunawati, dkk (2006). Hal ini juga akan membuat inefektivitas bimbi-ngan karena maksud dari dosen tidak tersampaikan kepada mahasiswa, dan mahasiswa juga akan semakin enggan untuk bertemu dosen sehingga akan berakibat pada intensitas bimbingan.

Sedangkan dari sisi dosen, jadwal mengajar dan tugas yang banyak membuat dosen kesulitan dalam membagi waktu. Akibatnya, dosen tidak dapat menjadwalkan waktu bimbingan dan terkadang mengesampingkan kewajibannya dalam membimbing mahasiswa skripsinya. Padahal peran dosen pembimbing dalam terselesaikannya skripsi sangat besar. Mahasiswa membutuhkan arahan dan bimbingan untuk mengatasi kesulitannya dalam mengerjakan skripsi, selain itu terdapat banyak urusuan administrasi skripsi yang berkaitan dengan dosen. Hal ini sesuai dengan hasil penelitian dari Wangid dan Sugiyanto (2014) terkait pentingnya kehadiran dosen dalam proses pengerjaan skripsi. Sehingga, semakin sedikit waktu yang diluangkan dosen untuk membimbing skripsi mahasiswa, maka semakin rendah pula kualitas dari intensitas bimbingan skripsi tersebut. Rendahnya intensitas bimbingan ini akan menghambat proses pengerjaan skripsi dan menjadi penyebab dari keterlambatan penyelesaian skripsi oleh mahasiswa.

Faktor eksternal yang terakhir adalah ketersediaan referensi. Peran fakultas maupun Universitas sangat besar dalam menyediakan fasilitas referensi ini. Namun kenyataan di lapangan menyebutkan, bahwa kebanyakan mahasiswa masih kesulitan dalam mendapatkan teori dan artikel yang sesuai dengan penelitian mereka. Hartato (2016) menekankan bahwa referensi menjadi hal yang penting bagi mahasiswa dalam proses pengerjaan skripsi. Karena skripsi merupakan suatu karya tulis ilmiah, maka dalam proses pengerjaannya harus ditunjang dengan teori-teori yang relevan dan penelitian terdahulu. Jika mahasiswa tidak bisa mendapatkan referensinya, maka proses pengerjaan skripsipun harus berhenti, dan terancam harus ganti judul. Sehingga, faktor referensi ini menjadi salah satu alasan mahasiswa mengalami keterlambatan dalam menyelesaikan skripsinya. 


\section{KESIMPULAN}

Berdasarkan hasil dan pembahasan, maka kesimpulan yang peniliti dapatkan terkait mengapa terjadi keterlambatan penyelesaian skripsi oleh mahasiswa jurusan Ekonomi Pembangunan Fakultas Ekonomi Universitas Negeri Malang, hal ini dikarenakan terdapat faktor internal dan faktor eksternal yang mempengaruhi proses penyelesaian skripsi: 1) Faktor Internal, meliputi faktor kesehatan, lemahnya motivasi, minat, kesulitan menentukan topik/permasalahan penelitian, kesulitan dalam mengumpulkan dan menganalisis data penelitian, pengalaman dalam menulis kerya tulis ilmiah, bekerja, aktif organisasi, serta rendahnya kemampuan siswa dalam manaje-men waktu ini didukung oleh 4 (empat) kecerdasan yang ada dalam diri mahasiswa. Kecerda-san yang dimaksud adalah IQ, EQ, AQ, dan SQ. Keempat cerdasan tersebut harus terpenuhi dan berjalan beriringan. Keempat kecerdasan ini juga masih juga akan mendukung mahasiswa dalam menanggapi faktor-faktor eksternal yang mempersulit proses pengerjaan skripsi; 2) Faktor Eksternal, yang dapat mempengaruhi keterlambatan penyelesaian skripsi mahasiswa, meliputi ketersediaan motivasi dari keluarga referensi, relasi antara dosen dengan mahasiswa, motivasi dari keluarga dan teman sebaya.

Mengacu pada temuan penelitian, maka penulis sarankan kepada para dosen pembimbing, pihak jurusan EKP FE-UM, pihak Universitas Negeri Malang, dan bagi mahasiswa tingkat akhir, agar hasil penelitian ini dijadikan bahan evaluasi dan acuan kedepannya sehingga berbagai hambatan atau kendala dalam menyelesaikan skripsi ini dapat di selesaikan dengan baik.

\section{DAFTAR PUSTAKA}

Baharuddin dan Wahyuni, Esa Nur (2010) Teori Belajar dan Pembelajaran. Jogjakarta : Ar-Ruzz Media.

Barnes, John (2014) Why Do MBA (Master of Business Administration) Students

Delay Completing Their Thesis?. Lectures at Assumption University, Graduate School of Business.

Dalman.(2014). Menulis Karya Ilmiah. Jakarta: PT Raja Grafindo Persada.

Efendi, Agus. 2005. Revolusi Kecerdasan Abad 21. Bandung: Alfabeta.

Gunawati, dkk (2006). Hubungan Antara Efektivitas Komuniasi Mahasiswa Dosen Pembimbing Utama Skripsi dengan Stres dalam Menyusun Jurnal penelitian: Progam Studi Psikologi Fakultas Kedokteran Universitas Diponegoro. Jurnal Psikologi, 3 (2): 93-115.

Hamalik, Oemar. 2003. Proses Belajar Mengajar. Jakarta: PT Bumi Aksara.

Hamidi, dkk. (2013) Faktor-faktor yang Mempengaruhi Motivasi Mahasiswa dalam Penyelesaian Skripsi (Studi Terhadap Mahasiswa Bimbingan dan Konseling Angkatan 2006-2007 STKIP PGRI Sumatera Barat). Skripsi. STKIP PGRI Sumatera Barat.

Hartato, Ujang. (2016) Faktor-faktor yang Mempengaruhi Penyelesaian Tugas Akhir Skripsi (TAS) Mahasiswa Progam Studi Pendidikan Akuntasi 
Fakultas Ekonomi Universitas Negeri Yogyakarta Angkatan 2011. Jurnal Penelitian: Fakultas Ekonomi Universitas Negeri Yogyakarta.

Khasanah, Anna Khalida. (2015). Faktor-Faktor yang Mempengaruhi Kesulitan Belajar Mata Pelajaran Otomatisasi Perkantoran Siswa Kelas X Program Keahlian Administrasi Perkantoran SMK Negeri 2 Semarang Tahun ajaran 2014/2015. Jurnal Penelitian: Fakultas Ekonomi. Universitas Negeri Semarang.

Korir, D.K dan Kipkemboi, Felix. (2014) The Impact of School Environment and Peer Influences on Students' Academic Performance in Vihiga Country, Kenya. International Journal of Humanities and Social Science, 4(5): 240251.

Kusnendar, dkk. (2012) Analisis Penghambat Penyelesaian Studi Mahasiswa S1 Program Studi Pendidikan Teknik Mesin Jurusan Pendidikan Teknik dan Kejuruan Fakultas Keguruan dan Ilmu Pendidikan Universitas Sebelas Maret Surakarta. Jurnal Universitas Sebelas Maret Surakarta.

Maanesh, Stilla.(2009) Siap Kuliah agar Kamu Tahu Bagaimana jadi Mahasiswa. Jakarta : Gagas Media.

Marantika, Inun. (2007) Pengaruh Keaktifan Organisasi Ekstrakurikuler dan Motivasi Belajar Terhadap Prestasi Belajar Mahasiswa Fakultas Ekonomi Universitas Negeri Malang. Skripsi, Jurusan Ekonomi Pembangunan Fakultas Ekonomi Universitas Negeri Malang

Mariana, Rachmawati. (2013) Hubungan Antara Optimisme dengan Coping Stress pada Mahasiswa Tingkat Akhir yang Bekerja Part Time dalam Menghadapi Skripsi. Jurnal Psikologi Universitas Brawijaya Malang.

Mujahidah, Indah Nur. (2014) Hubungan Antara Manajemen Waktu dengan Prokrastinasi Penyusunan Skripsi Pada Mahasiswa Universitas Muhammadiyah Surakarta. Naskah Publikasi. Fakultas Psikologi Universitas Muhammadiyah Surakarta.

Mushtaq, Irfan dan Khan, S.N (2012) Factors Affecting Students' Academic Performance. Global Journal of Management and Business Research, 12 (9): 17-22.

Pujiyanto. (2005) Pengaruh "Bekerja” terhadap Prestasi Mahasiswa Progam Studi Desain Komunikasi Visual Jurusan Seni dan Desain Fakultas Sastra UM. Jurnal Bahasa dan Seni, (1): 148-164.

Putri, Dinnar T.N dan Isnani, Gatot (2015). Pengaruh Minat dan Motivasi terhadap Hasil Belajar pada Mata Pelajaran Pengantar Administrasi Perkantoran. Jurnal Pendidikan Bisnis dan Manajemen, 1 (2): 118 -124.

Rusmiasih (2013) Pengaruh Motivasi dan Disiplinan Belajar Terhadap Hasil Belajar Ekonomi Siswa Kelas XI IPS di SMA N 10 Purworejo. Jurnal OIKONOMIA, 2 (3): 189-194

Santrock, J.W. 2012. Life-Span Development (Perkembangan Masa Hidup Edisi 13 Jilid 1, Penerjemah: Widyasinta). Jakarta: Erlangga.

Siswanto, Ibnu dan Sampuno, Y. G. (2012) Faktor-faktor Penghambat Penyelesaian Tugas Akhir Skripsi Mahasiswa Pendidikan Teknik Otomotif FT UNY. E-journal. (staff.uny.ac.id), diakses pada 13 Juni 2016.

Slameto. (2010) Faktor-faktor yang Mempengaruhi Belajar. Jakarta: PT Rineka Cipta. 
Sudharta, Nurwidi A. (2012) Prestasi Belajar Mahasiswa Angkatan 2008 sampai 2010 di Sekolah Tinggi Ilmu Ekonomi Surakarta Ditinjau dari Aktivitas Bekerja dan Cara Belajar Mahasiswa. Skripsi thesis. Universitas Muhammadiyah Surakarta.

Supiana (2013) Pengaruh Motivasi terhadap Hasil Belajar Siswa Kelas XC pada Mata Pelajaran Ekonomi di SMA. Artikel Penelitian. Fakultas Keguruan dan Ilmu Pendidikan Universitas Tanjungpura Pontianak.

Universitas Negeri Malang. (2012) Pedoman Pendidikan Universitas Negeri Malang. Malang: Biro Administrasi Akademik, Kemahasiswaan, Perencanaan, Informasi, dan Kerja Sama Universitas Negeri Malang.

Wangid, M. N dan Sugiyanto. (2014) Identifikasi hambatan struktural dan Kultural Mahasiswa dalam Menyelesaikan Tugas Akhir. Jurnal Penelitian Ilmu Pendidikan, 6 (2): 19-28

Widodo, dkk. (2010) Efektivitas Bimbingan Tugas Akhir Skripsi (TAS) Mahasiswa Jurusan Pendidikan Fisika FMIPA UNY. Prossiding Seminar Nasional Pendidikan, Pendidikan dan Penerapan MIPA. Fakultas MIPA. Universitas Negeri Yogyakarta. 